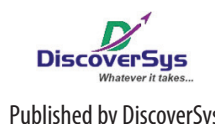

Published by DiscoverSys

\section{Association between participation in a chronic disease management program, medication adherence and decrease of blood pressure}

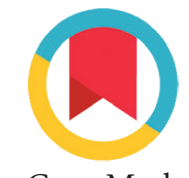

CrossMark

\author{
I Ketut Indra Wiguna Cakera, ${ }^{1}$ Ni Made Sri Nopiyani, ${ }^{2 *}$ I Made Ady Wirawan ${ }^{2}$
}

\section{ABSTRACT}

Background and purpose: The prevalence of hypertension is increasing globally. A comprehensive approach is necessary including a community based chronic disease management program which has been implemented in public health centres in Indonesia. Only few studies have been published in Indonesia that evaluate the program, especially regarding the management of hypertension in primary care settings. This study aims to examine the association between participation in a chronic disease management program, medication adherence and decrease of blood pressure.

Methods: A cross-sectional study was conducted in public health centres in Tabanan District. A total of 136 patients with hypertension were recruited at five groups that participate in the community based chronic disease management program called Program Pengelolaan Penyakit Kronis (Prolanis). The prolanis groups were purposively selected based on the size of participants in the program. One group was selected at urban area and four groups at rural areas. Data were collected from May to June 2017 by conducting interviews, blood pressure measurements, and secondary data extraction from the medical record of the prolanis database. The logistic regression analysis was used to determine the association between participation in a chronic disease management program, medication adherence and decrease of blood pressure.

Results: As many as $75.7 \%$ of respondents actively participated in the prolanis program, and $81.6 \%$ were found with decreased blood pressure. Our study found a significant association between blood pressure decrease and active participation in the prolanis program with an adjusted odds ratio (AOR) of 6.38 (95\% Cl: 1.96-20.79), the good adherence towards medication with $A 0 R=11.94(95 \% \mathrm{Cl}: 3.60-39.56)$, and routine physical activities with $\mathrm{AOR}=3.84$ ( $95 \% \mathrm{Cl}: 1.16-12.73$ ).

Conclusion: Active participation in the prolanis program, good adherence to medication and routine physical activities are independent factors of decreased blood pressure. These findings suggest the need for scaling up the prolanis program and increasing its coverage.

Keywords: community based program, chronic disease management, adherence to medication, prolanis

Cite This Article: Cakera, I.K.I.W., Nopiyani, N.M.S., Wirawan, I.M.A. 2018. Association between participation in a chronic disease management program, medication adherence and decrease of blood pressure. Public Health and Preventive Medicine Archive 6(2): 119-123. D01:10.15562/phpma. v6i2.136

${ }^{1}$ Marga II Public Health Centre, Tabanan,

${ }^{2}$ Department of Public Health and Preventive Medicine, Faculty of Medicine, Udayana University

*Correspondence to:

Ni Made Sri Nopiyani, Department of Public Health and Preventive Medicine, Faculty of Medicine, Udayana University mdsrinopiyani@yahoo.com

\section{INTRODUCTION}

Globally, the total of hypertension cases has increased from 600 million people in 1980 to one billion people in 2008. ${ }^{1}$ Mortality rates from cardiovascular diseases are 17 million per year globally, where as many as 9.4 million are directly associated with hypertension complications. ${ }^{1}$ Hypertension is also a public health concern in Indonesia with the prevalence of $26.5 \%$ among population aged $\geq 18$ years old. ${ }^{2}$ Hypertension is the second most common diseases treated at public health centres in Bali Province with a total cases of 89,394 people, and Tabanan District with a total of 24,398 cases. ${ }^{3,4}$ The Implementing Agency of National Health Insurance in Indonesia (called Badan Penyelenggara Jaminan Sosial (BPJS $)^{5}$ has implemented a chronic disease management program as a preventive measure (called Program Pengelolaan Penyakit Kronis (Prolanis). It consists of several activities which include medical consultation, health education, physical exercises, a reminder through text messages and home visit. ${ }^{6}$ The prolanis program has been implemented in Tabanan District since December 2015 with a total of seven prolanis groups. ${ }^{7}$

Only few studies have been published in Indonesia that evaluate the program, especially regarding the management of hypertension in primary care settings. The aim of this study was to examine the association between participation in a chronic disease management program, medication adherence and decrease of blood pressure among patients with hypertension who participated in the prolanis program.

\section{METHODS}

A cross-sectional survey was conducted among 136 patients with hypertension who participated in prolanis program at public health centres in Tabanan 
District. The number of samples was calculated with a confidence level of $95 \%$, power $80 \%$ and $20 \%$ difference of adherence proportion between those who active and not active participated in a support group program. ${ }^{8}$

This study included prolanis groups from public health centres that have an average weekly visit of $75 \%$ and above based on the first-trimester report in 2016. The prolanis groups in this study were purposively selected based on three criterias. Firstly, based on the local regulation of Tabanan District which categorized public health centres as urban or rural. Secondly, based on the size of capitation under the national health insurance scheme. Thirdly, based on the intensity of the implementation of prolanis program. The intensity was determined based on weekly activities recorded in the 2016 monitoring report provided by BPJS Denpasar. The prolanis group from Kediri I Public Health Centre (PHC) was selected to represent urban areas, and four prolanis groups from four health centres (Penebel I, Marga II, Kerambitan II and Kediri III) were selected to represent rural areas. The total number of participants in these five PHCs was 163 people and the 136 samples were selected randomly from these 163 participants.

Data were collected from May to June 2017 by conducting interviews, blood pressure measurements, and secondary data extraction from the medical record of the prolanis database. Data collection was conducted by four trained enumerators. Data collected were sociodemographic characteristics, participation in the prolanis program, adherence to medication, blood pressure, history of hypertension in the family, age, salt and alcohol consumption, smoking history, obesity, and stress level. Participation in the prolanis program was scored based on the attendance in three consecutive weeks and engagement in the prescribed programs of morning exercise and group health education. Attendance was scored zero if respondents did not participate three times consecutively, scored one if respondents forgot and scored two if respondents never being absent three times in a row. Engagement in morning exercise and health education was scored zero if respondents never participated in the whole session of each activity and scored one, two, three if they rarely, frequently, always participated in the whole sessions of morning exercise and health education. Participation was categorized as not active if the total score was below five and as active if the total score was five and above. Adherence to medication was measured using the Morisky Medication Adherence Scale/MMAS-8. Blood pressure was obtained from the medical record as a baseline and the follow up measurement was conducted during the survey using a sphygmomanometer that available at PHC. The hypertension categories referred to the Eight Joint National Committee (JNC-8) Guideline 2014 and the blood pressure is defined as "decrease" if there is a one level decrement. ${ }^{9}$ Data on sociodemographic characteristics, hypertension history in the family, salt and alcohol consumption, physical activity, smoking history, obesity, and stress level were obtained by face to face individual interviews using a pre-tested questionnaire.

Data were analyzed to describe the frequency and distribution of respondents and chi-square test was used to determine the association between blood pressure decrease and independent variables. All independent variables with $\mathrm{p}$-value $<0.25$ were included in the multivariate analysis using logistic regression to determine the adjusted odd ratio (AOR) of participation in the prolanis program and adherence to medication on the blood pressure decrease. This study has been approved by the Human Research Ethics Committees Faculty of Medicine Udayana University/Sanglah General Hospital Denpasar in March 2017.

\section{RESULTS}

The mean age of respondents was $65.6(\mathrm{SD}=9.3)$ years-old. The majority of respondents were females (61.8\%), with low educational attainment (48.6\%), and working in the home industry (22.1\%). As many as $21.3 \%$ of respondents were from the prolanis groups located in urban areas (Kediri I Public Health Centre), and $75.7 \%$ of respondents actively participated in the prolanis program. Decreased blood pressure was observed in $81.6 \%$ of the respondents, and $72.1 \%$ of respondents were found to have good adherence towards their medication. These findings can be seen in Table 1 .

Table 2 shows that participation in prolanis program $\quad(\mathrm{AOR}=6.38 ; \quad 95 \% \mathrm{CI}: \quad 1.96-20.79)$, adherence to medication $(\mathrm{AOR}=11.94 ; 95 \% \mathrm{CI}$ : 3.60-39.56), and physical activity $(\mathrm{AOR}=3.84$; 95\%CI: 1.16-12.73) were independently associated with blood pressure decrease. Salt consumption was not associated with the decreased blood pressure when other variables were taken into account with an AOR of 1.81 (95\%CI: 0.42-7.82).

\section{DISCUSSION}

Our study found that a total of 103 respondents $(75.7 \%)$ were actively engaged in the prolanis program, and 111 respondents (81.6\%) had a decreased blood pressure after participated in the program for the last 12 months. The participation in the prolanis program found in the present study is similar with the previous study conducted in 
Table 1 Characteristics of respondents

\begin{tabular}{|c|c|c|}
\hline Characteristics & $\mathbf{n}$ & $\%$ \\
\hline \multicolumn{3}{|l|}{ Age (years) } \\
\hline $37-64$ & 59 & 43.4 \\
\hline $65-86$ & 77 & 56.6 \\
\hline \multicolumn{3}{|l|}{ Gender } \\
\hline Male & 52 & 38.2 \\
\hline Female & 84 & 61.8 \\
\hline \multicolumn{3}{|l|}{ Education } \\
\hline Never and primary (elementary and junior high) & 66 & 48.6 \\
\hline Senior high school & 34 & 25.0 \\
\hline Tertiary (diploma, university) & 36 & 26.5 \\
\hline \multicolumn{3}{|l|}{ Occupation } \\
\hline Farmers & 23 & 16.9 \\
\hline Home industries & 30 & 22.1 \\
\hline Merchants & 23 & 16.9 \\
\hline Office workers (government and private sectors) & 15 & 11.0 \\
\hline Retired & 25 & 18.4 \\
\hline Housewives and others & 20 & 14.7 \\
\hline \multicolumn{3}{|l|}{ Prolanis group } \\
\hline Penebel I & 37 & 27.2 \\
\hline Kerambitan II & 30 & 22.1 \\
\hline Kediri I & 29 & 21.3 \\
\hline Kediri III & 13 & 9.6 \\
\hline Marga II & 27 & 19.9 \\
\hline \multicolumn{3}{|l|}{ Participation in prolanis program } \\
\hline Not active (score $0-4$ ) & 33 & 24.3 \\
\hline Active (score 5-8) & 103 & 75.7 \\
\hline \multicolumn{3}{|l|}{ Blood pressure } \\
\hline Remained or increased & 25 & 18.4 \\
\hline Decreased & 111 & 81.6 \\
\hline \multicolumn{3}{|l|}{ Adherence to medication } \\
\hline Poor $($ score $<6)$ & 38 & 27.9 \\
\hline Good (score 6-8) & 98 & 72.1 \\
\hline Total & 136 & 100.0 \\
\hline
\end{tabular}

Table 2 Association between blood pressure decrease and some variables

\begin{tabular}{|c|c|c|c|c|c|c|c|}
\hline \multirow[b]{3}{*}{ Variables } & \multicolumn{3}{|c|}{ Bivariate } & \multirow[b]{3}{*}{$\mathbf{p}$} & \multicolumn{3}{|c|}{ Multivariate } \\
\hline & \multicolumn{2}{|c|}{$\begin{array}{c}\text { Blood pressure } \\
\text { decrease }\end{array}$} & \multirow{2}{*}{$\begin{array}{l}\text { Total } \\
\text { n (\%) }\end{array}$} & & \multirow[b]{2}{*}{ AOR } & \multirow[b]{2}{*}{$95 \% \mathrm{Cl}$} & \multirow[b]{2}{*}{$\mathbf{p}$} \\
\hline & Yes (\%) & No (\%) & & & & & \\
\hline \multicolumn{8}{|l|}{$\begin{array}{l}\text { Participation in prolanis } \\
\text { program }\end{array}$} \\
\hline Not active (score $0-4$ ) & $17(51.5)$ & $16(48.5)$ & $33(24.3)$ & & 1.00 & & \\
\hline Active (score 5-8) & $94(91.3)$ & $9(8.7)$ & $103(75.7)$ & $<0.01$ & 6.38 & $1.96-20.79$ & $<0.01$ \\
\hline
\end{tabular}




\begin{tabular}{|c|c|c|c|c|c|c|c|}
\hline \multirow[b]{3}{*}{ Variables } & \multicolumn{3}{|c|}{ Bivariate } & \multirow[b]{3}{*}{$\mathbf{p}$} & \multicolumn{3}{|c|}{ Multivariate } \\
\hline & \multicolumn{2}{|c|}{$\begin{array}{c}\text { Blood pressure } \\
\text { decrease }\end{array}$} & \multirow{2}{*}{$\begin{array}{l}\text { Total } \\
\text { n (\%) }\end{array}$} & & \multirow[b]{2}{*}{ AOR } & \multirow[b]{2}{*}{$95 \% \mathrm{Cl}$} & \multirow[b]{2}{*}{$\mathbf{p}$} \\
\hline & Yes (\%) & No (\%) & & & & & \\
\hline \multicolumn{8}{|c|}{ Adherence to medication } \\
\hline Poor (score 0-5) & $18(47.4)$ & $20(52.6)$ & $38(27.9)$ & & 1.00 & & \\
\hline Good (score 6-8) & $93(94.9)$ & $5(5.1)$ & $98(72.1)$ & $<0.01$ & 11.94 & $3.60-39.56$ & $<0.01$ \\
\hline \multicolumn{8}{|l|}{$\begin{array}{l}\text { Family history of high } \\
\text { blood pressure }\end{array}$} \\
\hline Yes & $77(80.2)$ & $19(19.8)$ & $96(70.6)$ & & & & \\
\hline No & $34(85.0)$ & $6(15.0)$ & $40(29.4)$ & 0.51 & & & \\
\hline \multicolumn{8}{|l|}{ Age (years) } \\
\hline $37-64$ & $48(81.4)$ & $11(18.6)$ & $59(43.4)$ & & & & \\
\hline $65-86$ & $63(81.8)$ & $14(18.2)$ & $77(56.6)$ & 0.95 & & & \\
\hline \multicolumn{8}{|l|}{ Salt consumption } \\
\hline High (score >2) & $13(68.4)$ & $6(31.6)$ & $19(14.0)$ & & 1.00 & & \\
\hline Normal (score $\leq 2$ ) & $98(83.8)$ & $19(16.2)$ & $117(86.0)$ & 0.11 & 1.81 & $0.42-7.82$ & 0.43 \\
\hline \multicolumn{8}{|l|}{ Alcohol consumption } \\
\hline Yes & 0 & $1(100.0)$ & $1(0.7)$ & & & & \\
\hline No & $111(82.2)$ & $24(17.8)$ & $135(99.3)$ & $-*$ & & & \\
\hline \multicolumn{8}{|l|}{ Physical activity } \\
\hline Not routine & $36(69.2)$ & $16(30.8)$ & $52(38.2)$ & & 1.00 & & \\
\hline Routine & $75(89.3)$ & $9(10.7)$ & $84(61.8)$ & $<0.01$ & 3.84 & $1.16-12.73$ & 0.03 \\
\hline \multicolumn{8}{|l|}{ Currently smoking } \\
\hline No & $111(82.2)$ & $24(17.8)$ & $135(99.3)$ & & & & \\
\hline Yes & 0 & $1(100.0)$ & $1(0.7)$ & $-*$ & & & \\
\hline \multicolumn{8}{|l|}{ Normal BMI } \\
\hline No & $51(81.0)$ & $12(19.0)$ & $63(46.3)$ & & & & \\
\hline Yes & $60(82.2)$ & $13(17.8)$ & $73(53.7)$ & 0.85 & & & \\
\hline \multicolumn{8}{|l|}{ Stress level } \\
\hline High (score >7) & $4(66.7)$ & $2(33.3)$ & $6(4.4)$ & & & & \\
\hline Normal (score $\leq 7$ ) & $107(82.3)$ & $23(17.7)$ & $130(95.6)$ & 0.33 & & & \\
\hline Total & $111(81.6)$ & $25(18.4)$ & $136(100.0)$ & & & & \\
\hline
\end{tabular}

*Analysis could not be performed

Tabanan District in 2016. ${ }^{7}$ Both studies found that the participation rates of above $75 \%$. Patients also expressed high satisfaction score and a high score on the perceived benefits of the program for their health outcomes. ${ }^{7}$ Our study found that as many as 98 respondents $(72.1 \%)$ adhered to their medication. This finding is much higher than the results of a study conducted in Klungkung District in 2014 which found the adherence rates of only $36.1 \%{ }^{10}$ The study conducted in Klungkung involved only out-patients with hypertension who seek treatment from the public health centres which did not implement the prolanis program. Patients who attend the prolanis program received health education programs and support group activities that likely to lead to higher adherence towards medication.

Participation in the prolanis program was independently associated with decreased blood pressure. Active participation in the prolanis program will expose patients with ongoing information allowing better management of hypertension including improved adherence to medication which leads to better control of the blood pressure. Several studies on the elderly health programs found similar results, for example, a study conducted in Banyumas District in 2011 found that the participation of elderly in the integrated health services which called pos pelayanan terpadu 
(posyandu) was positively associated with their overall health status. ${ }^{8}$ A study in Denpasar City in 2012 also found that the physical exercise program for elderly significantly decreased the systolic and diastolic blood pressure. ${ }^{11}$ Our study also found that adherence to medication was significantly associated with decreased blood pressure among hypertensive patients who participated in the prolanis program. This finding is consistent with other studies which found a positive association between adherence to medication and blood pressure control. A study in North Lampung found a positive association between adherence towards medication and blood pressure control. ${ }^{12}$ Another study in Alabama, the USA in 2015 found that the adherence to antihypertensive drugs was associated with a better blood pressure control. ${ }^{13}$

Physical activities outside of the prolanis program were also found to significantly reduce the blood pressure among those who participate in the program. This finding is consistent with another study in Surabaya City in 2015 which found that there was a significant association between physical exercise and the prevalence of hypertension. ${ }^{14}$ Studies in Denpasar City in 2012 and Manado in 2015 also found similar trend indicating a significant association between physical exercise program for elderly and a better control of blood pressure. ${ }^{11,15}$

The association found in the current study, however, is not a causal relationship. The effects of some variables could not be examined due to the relatively small sample size.

\section{CONCLUSION}

Active participation in the prolanis program, good adherence to medication and routine physical activities are independent factors of decreased blood pressure. These findings suggest the need for scaling up the prolanis program and increasing its coverage.

\section{ACKNOWLEDGEMENT}

We would like to thank the Head of Tabanan District Health Office, study enumerators, and all respondents who had participated in this study.

\section{REFERENCES}

1. World Health Organization. A global brief on hypertension: Silent killer, global public health crisis. Geneva: World Health Organization, 2013

2. Ministry of Health of Indonesia. Riset Kesehatan Dasar 2013 [The 2013 Indonesia Basic Health Research]. Jakarta: Ministry of Health of Indonesia, 2013.

3. Bali Provincial Health Office. Profil Dinas Kesehatan Provinsi Bali Tahun 2015 [The 2015 Profile of Bali Province Health Office]. Denpasar: Bali Provincial Health Office, 2015.
4. Tabanan District Health Office. Profil Dinas Kesehatan Kabupaten Tabanan Tahun 2014 [The 2014 Profile of Tabanan District Health Office]. Tabanan: Tabanan District Health Office, 2014.

5. The Indonesian Government. Undang-undang No. 24 Tahun 2011 tentang Badan Penyelenggara Jaminan Sosial [Law No.24 Year 2011 on The Implementing Body of Social Insurance]. Lembaran Negara RI Tahun 2011, No.116. Tambahan Lembaran Negara RI No. 5256. Sekretariat Negara. Jakarta, 2011.

6. The National Health Insurance Implementing Body. Panduan praktis prolanis (program pengelolaan penyakit kronis) [Practical guidelines on prolanis program (chronic diseases management program)]. pp.3-6. Jakarta: The National Health Insurance Implementing Body, 2010.

7. Lestari NLI. Analisis implementasi Program Pengelolaan Penyakit Kronis (Prolanis) pada Puskesmas di Kabupaten Tabanan [Analysis on the implementation of chronic diseases management program (Prolanis) at public health centers in Tabanan District]. Community Health. X. 2016.

8. Dwi R, Susanti I, Yudhono D. 2011. Hubungan keaktifan lansia dalam kegiatan posyandu lansia dengan tingkat kesehatan lansia di Desa Ledug Kecamatan Kembaran Kabupaten Banyumas (skripsi) [Association of elderly participation in the integrated health services with their health status in Ledug Village, Kembaran Sub-district, Banyumas District (undergraduate thesis)]. Purwokerto STIKES Harapan Bangsa.

9. Bell K, Twigss J, Olin BR. Hypertension: The Silent Killer: Updated JNC-8 Guideline Recommendations. Alabama Pharmacy Association; 2015. [cited 2017 January 3]. Available from: https://cdn.ymaws.com/www.aparx.org/ resource/resmgr/CEs/CE_Hypertension_The_Silent_K. pdf.

10. Pratama GW. 2014. Faktor-faktor yang mempengaruhi kepatuhan pengobatan hipertensi pada lansia binaan Puskesmas Klungkung 1 (skripsi) [Factors influencing the adherence of hypertension treatment among elderly at Klungkung 1 Public Health Center (undergraduate thesis)]. Denpasar: Universitas Udayana.

11. Astari PD, Adiatmika PG, Pande D. 2012. Pengaruh senam lansia terhadap tekanan darah lansia dengan hipertensi pada kelompok senam lansia di Banjar Kaja Sesetan Denpasar Selatan (skripsi) (The influence of elderly physical activities on blood pressure of elderly with hypertension in a group of elderly exercises in Banjar Kaja Sesetan South Depasar (undergraduate thesis)]. Denpasar: Universitas Udayana.

12. Mariani R, Susilawati F. Faktor yang berhubungan dengan tingkat hipertensi pada pasien hipertensi di RSU Handayani Kotabumi Lampung Utara [Factors associted with hypertension among hypertension patients in Handayani Hospital Kotabumi North Lampung]. Jurnal Kesehatan Metro Sai Wawai 2015; VIII: 8-12.

13. Piercefield EW, Howard ME, Robinson MH, Kirk CE, Ragan AP, Reese SD. Antihypertensive medication adherence and blood pressure control among Central Alabama veterans. Journal of Clinical Hypertension. 2017; 19: 543-549.

14. Putriastuti L. Analisis hubungan antara kebiasaan olahraga dengan kejadian hipertensi pada pasien usia 45 tahun keatas [Analysis on the association of exercises with hypertension among patients aged 45 years or above]. Jurnal Berkala Epidemiologi. 2016; 4; 2: 225-236.

15. Lumempouw D. Pengaruh senam prolanis terhadap penyandang hipertensi [The influence of prolanis exercises on hypertension patients]. Jurnal e-Biomedik. 2016: 4(1).

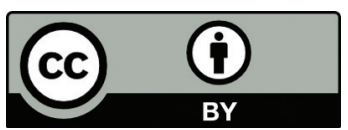

This work is licensed under a Creative Commons Attribution 